\title{
Inventing the Barbarians: The Changing Contexts of Yi in the Late Qing Dynasty
}

\author{
Xinying $\mathrm{Hu}^{1, \text { a }, ~},{ }^{\dagger}$ Linyi Zheng ${ }^{2, \mathrm{~b}, *, \dagger}$ \\ ${ }^{1}$ School of Social Work, China University of Labor Relations, Beijing, P.R.China. \\ ${ }^{2}$ School of International Studies, Peking University, Beijing, P.R.China. \\ ${ }^{*}$ Corresponding author.Email: ${ }^{a} 1890101070 @$ stu.culr.edu.cn, ${ }^{b}$ zhenglinyi@pku.edu.cn \\ These authors contributed equally.
}

\begin{abstract}
This study analyses how the meaning of yi (夷, barbarian) was constructed in different historical contexts at the end of the Qing dynasty, which is important for us to reconsider xenophobia and Sino-centrism both in the past and present. Our study combines contextual with intertextual reading methods. It places different materials, including missionaries' works, newspapers, and official documents, in their specific historical contexts and links them to obtain a full picture of this transformation. We argue that yi was invented. Various agents and actors created the connotation of yi to suit their interests. It was transformed by the Qing court from "barbarians" to those who follow Confucianism to justify their rule. Then it was first translated as "foreigners" and later as "barbarians" when Europeans came to China. Our study situates the meaning of yi to help us rethink some of the labels and misconceptions attached to yi and the early missionaries in China.
\end{abstract}

Keywords: hua-yi distinction, contexts, the late Qing dynasty, barbarian, foreigner, missionary.

\section{THE CONTEXT OF THIS ARTICLE}

As China' s economic status has begun to challenge the existing international order in recent years, the saying hua-yi zhi bian (华夷之辨 the distinction between China and $y i$ ) regains its power. Originally hua refers to the Han Chinese, while $y i$ means the neighboring ethnic groups with a pejorative implication, namely "barbarians." This term implies a Sino-centric view. Based on this explanation, the growth of Chinese power is interpreted as the revival of Sino-centrism - "China and the barbarians are different." [1] However, the meaning of $y i$ changed in history, from Han Chinese to Chinese, from foreigners to barbarians, and vice versa. In general, its meaning is more likely to be transformed during the transitional periods. This research is to examine this shift in the late Qing. How and why did the meaning of $y i$ change? Who did participate in this process? What kinds of roles did the missionaries play?

There are few studies specifically dealing with the translation of $y i$ in the late Qing. Most scholars simply mentioned it when they talked about missionaries and correspondingly attached it with imperialism.
Liu noticed that the history of the translation of $y i$ was convoluted and neglected. Still, the expressions of $y i$ in newspapers and books impacted Sino-British relations, and she argued that the reason for the changing meaning of $y i$ is to help the Western European invaders [2]. Frank argued that Europeans' stereotypes of the late Qing dynasty stem from their holding a Eurocentric view [3]. To analyse the changing meaning of $y i$ more objectively requires a relatively unbiased global perspective based on various materials.

As Wang argued, previous studies are too one-sided, and we should notice that the essential purpose of the early Protestant missionaries was to expand the Church's influence. In the process, they served to facilitate cultural exchange between China and the West [4]. This suggests that we cannot generalise the purposes and roles of missionary activities in China but need to consider their performance in a specific historical context.

In terms of Chinese and foreign diplomatic relations at that time, $\mathrm{Li}$ divides the late Qing government's acceptance of foreign ministers in China into four stages [5], providing us a comparatively systematic account of Chinese and foreign diplomacy in different historical 
periods. It is worth noting that the Chinese understanding of the character $y i$ was multifaceted. In the late Qing dynasty, foreigners were excluded, and their activities in China were restricted, so it was reasonable to translate $y i$ as "strangers," "foreigners," and "barbarians" [6].

Existing research has confined itself to pointing out missionaries' attitudes towards China and consequently labeling them as cultural invaders. Our study is to reexamine these labels by including the translation of $y i$ into consideration.

A variety of materials are involved in this research. First, early missionaries' newspapers, journals, dictionaries, and even logbooks are used to see their experience in China and corresponding views of China. Specifically, August Gutzlaff's (1803-1851) Eastern Western Monthly Magazine, In Journal of Three Voyages along the Coast of China, in 1831, 1832, and 1833: With Notices of Siam, Corea, and the Loo-Choo Islands, The Canton Register, and The Chinese Repository. Second, official documents, including the Treaty of Tien-Tsin between the Queen of Great Britain and the Emperor of China (1858), the diplomatic letter between Lin Zexu (1785-1850) and Queen Victoria (1819-1901) are used to show the governments' attitudes. Methodologically, this research combines contextualized and inter-textual reading. By situating the materials in a specific historical context, it traces the change of $y i$ over time. Moreover, it links different materials together to get a full picture of this shift. And we study how China and foreign countries dealt with the problem of $y i$ in the late Qing dynasty through historical facts. We would criticize some ideas regarding missionaries before the First Opium War (1840) as colonizers and think that missionaries came to China to gain opium benefits.

This research demonstrates that the meaning of $y i$ was re/constructed and deconstructed in different historical periods through situated analysis. It was transformed from barbarians to Chinese who follow Confucianism by the Qing court to justify its rule. At the same time, it was translated as "foreigners" and re-translated as "barbarians" when the Europeans arrived in China. We argue that $y i$ was invented. The connotation of "barbarians" can be created by different actors to cater to their interests.

\section{THE CHANGING CONTEXTS OF HUA- YI(华夷)}

\subsection{How the Qing dynasty deconstructed and reconstructed hua-yi}

The meaning of hua-yi underwent a great transformation in the Qing dynasty.

After centuries of Manchu rule in the Middle Kingdom, the meaning of hua (华) gradually changed to refer to all ethnic groups in China. Meng proposed that the distinction between hua and yi could be both cultural and ethnic-geographical. Its emphasis shifted with the change of dynasties [7]. As non-Han Chinese, the first serious problem faced by the rulers was the strong antiManchu ideology in the society. Because hua-yi distinction dominated the land for a long time Han Chinese considered minorities as $y i$ (barbarians). They raised the banner of "Anti-Qing sentiment" (Fan qing fu ming, 反清复明) and 'restoration of Han China' (Guang fu hua xia, 光复华夏), denouncing the Manchus as unqualified rulers. Xiang argued that the rulers implemented the policy of ethnic oppression and economic development [8]. The policy of ethnic oppression shook the predominantly Han Chinese position in the Ming dynasty's perception of hua-yi, and the economic development led to greater stability for all ethnic groups. Therefore, the connotation of hua gradually included the Manchu ethnic groups. It is noticeable that $\mathrm{Li}$ noticed that the rulers of the Qing dynasty, on the one hand, emphasised the basic state policy of "Manchurian fundamentals." It established the dominant position of Manchurians in all aspects of their political, economic, cultural, and social life and maintained their privileges. On the other hand, the political strategy of "multi-ethnicity as one" was proposed. Based on safeguarding the Manchurians' interests, relevant policies were formulated in politics, ideology, and culture, economy, and ethno-religious relations to promote the integration of the various ethnic groups [9]. This allowed the hua-yi distinction to gradually become a geographical concept, without the derogatory meaning of $y i$ (barbarians) and simply referring to the peoples from the areas outside the Middle Kingdom.

In addition, $\mathrm{Li}$ argued that the Manchu rulers attached importance to "Confucianism and indoctrination" in their ideology and culture to build up the image of an orthodox dynasty. The traditional view of hua-yi distinguishes hua and $y i$ through whether or not they follow Confucian rituals. Therefore, the Manchu rulers valued Confucianism, studied it, and spread it widely among the people. Thus Manchu justified that they were not barbarians but reasonable rulers who also followed Confucian rites.

Secondly, there was also a significant change in the meaning of $y i$, which gradually evolved from ethnic minorities to foreigners. $y i$ was used to refer to the ethnic groups that did not obey Confucian rituals. Due to the Chinese rites controversy between Roman Catholic missionaries and Confucianism during the Kangxi period (1661-1722), the emperor Kangxi stated that missionaries in China would not stay in China if they opposed Chinese rites. However, an ambassador published the Pope's edict on his way back to Europe. This behaviour was seen as a challenge to the traditional 
Chinese rituals and laws. Thus Kangxi was angered and changed his liberal religious policy to restrict the missionary practices in the Qing dynasty [10]. The Qing dynasty, with Sino-centrism, witnessed a different cultural philosophy from the European missionaries. They did not follow Confucian rituals and therefore did not belong to the category of hua. And as European countries interacted increasingly closely with the Qing dynasty, the term $y i$ gradually became a synonym for foreigners.

\subsection{What the early missionaries experienced in China}

The late Qing was a period of dramatic change in Sino-Western relations, during which Britain was most closely involved with China. As one of the representatives of unofficial diplomacy, Chen pointed out that missionaries often played multiples roles, religious, commercial, and even political. Due to their ambiguous positions, some even lost their missionary status. Robert Morrison (1782-1834), one of the earliest Protestant missionaries in mainland China, was a key figure in the early history of Sino-British relations, with his great achievements in both missionary and political affairs [11]. Before the First Opium War, the Qing government severely restricted missionary activities. Zhang's description of the survival of the early missionaries and their families reveals that their individual freedom of movement was greatly restricted under the repressive policies, which even threatened their lives [12]. Morrison had to become involved in the official Chinese and British diplomacy to seek further missionary opportunities in the specific historical period. As an early Protestant missionary, Morrison's diplomatic activities were representative, defending British interests and reconciling them with Chinese interests.

Morrison saw a pejorative sense of $y i$, but did not translate $y i$ as "barbarians." Liu provided two pieces of evidence. The first translation of $y i$ as "foreigners" is in the Dictionary of the Chinese Language, and the second one is in archives in the East India Company before 1832 [13]. Wang argued that Morrison believes that yi contains the meaning of barbarism. He also cited at least two occasions when Morrison discusses the word $y i$ in a very explicit way, with its negative connotation: inferior and problematic. Those who understood the negative meaning of $y i$ protested this address, but the Chinese still called them $y i$. Thus these translators chose not to acknowledge and deliberately ignored the derogatory meaning of $y i$, refusing to further reinforce it [14]. In this period, at the official level, $y i$ was not equated with barbarians.

\section{BEFORE THE FIRST OPIUM WAR}

\subsection{How yi was translated as barbarians}

In the early 19th century, Chinese officials had the idea of the Celestial Empire (Tian chao shang guo, 天朝 上国) ostracizing foreign cultures. Before the 1830s in the late Qing dynasty, the relations between China and foreign countries were mainly commercial, and the European merchants could only operate in Guangzhou and Macao. For China, the main reason for not establishing diplomatic relations was the argument of huayi distinction (hua yi zhi bian, 华夷之辨), believing that China was the center of the globe and that other countries were vassal states or foreign $y i$ (Wai yi, 外夷) [15] who should pay tribute to China. The foreign yi did not know decency and justice. So as long as they did not threaten the central government, China did not need to communicate with them too much. They could just conciliate them or even never communicate with them. Since the Kangxi period, the Qing government had implemented a policy of banning missionary activities. After Qianlong's succession, missionary activities were strictly banned, and missionaries could only operate openly in Macao. Until the First Opium War, missionaries in Guangzhou were afraid to reveal their identity. Once the government detected their secret missionary activities, they would be strictly prohibited.

Mission was very difficult. One of the most important missionaries in the 19th century was Karl Friedrich August Gützlaff (1803-1851), who arrived in Macau in 1831. Alexander Wiley noted that "Gützlaff had commended himself to the natives, by the practice of medicine among them... while he distributed Christian books to a great extent, on every available occasion." [16] Gützlaff knew China very well, and he documented how his mission was discriminated against in China. He wanted to build an ANGLO -CHINESE COLLEGE, with the purpose of "blending the culture of Chinese and European literature, and rendering its advantages subservient to the advancement of the cause of Christ in China." [17] But the response he got was "the extreme ignorance of even the accomplished scholar of China respecting Christian nations." According to Gützlaff, one scholar congratulated himself in his article that he was not born in "our barbarous countries of the West." [18] It can be seen that not only were the missionary activities excluded in China, but the West was also seen as a "wilderness" that could not match China, but it was not true in reality. Gützlaff's experience in China affected his understanding of $y i$. He recorded the experience that he was viewed as "barbarians." Kroma-khun, the brother-inlaw of The Jiaqing Emperor (1760-1820), called in Gützlaff's medical help. Gützlaff thought that Kromakhun "greatly approved of Christian principles, but did not apply to the fountain of all virtue, Jesus Christ." [19] Kroma-khun again called in his aid in consequence of an 
ulcer; yet his arrogant son despised the assistance of a barbarian, and Kroma-khun soon died. Therefore, When Chinese officials referred to him as $y i$, he thought that Chinese officials regarded him as a barbarian.

\subsection{How missionaries' Chinese and English newspapers interpreted yi}

Gützlaff disagreed with Robert Morrison' s translation of $y i$ as foreigners. In 1833, he founded the first modern newspaper in mainland China in Chinese Eastern Western Monthly Magazine (Dong xi yang kao mei yue tong ji zhuan, 东西洋考每月统记传) in which he understood $y i$ as barbarians. Gützlaff's importance lies in the fact that "barbarian" has become the official translation of $y i$ from then on [20].

To introduce his newspaper to foreign readers, Gützlaff wrote an article in The Chinese Repository, in which he clearly expressed his dissatisfaction with the Chinese idea of the Celestial Empire and their calling foreigners $y i$ :

"While civilization is making rapid progress over ignorance and error in almost all other portions of the global -- even the bigoted Hindoos having commenced the publication of several periodicals in their languages -the Chinese alone remain stationary, as they have been for ages past. Notwithstanding our long intercourse with them, they still profess to be first among the nations of the earth and regard all others as 'barbarians.' This empty conceit has greatly affected the interests of foreign residents in Canton and their intercourse with Chinese [21]."

He thought that "the name of $y i$ refers to the people who are abusive." [22] He made an analogy with beasts to barbarians, stating that Westerners knew the etiquette, so Westerners should be human, not beasts. Gützlaff suggested using "guests from afar," [23] "westerners," "foreigners," and the names of their countries to refers to foreigners. Unlike hua-yi distinction, "guests" parallels "hosts." So there is no question of status. There is no derogatory sense. The idea of guests from afar is in line with traditional Confucianism in China. Confucius said in Xue Er ( “学而”) “ 'Is it not delightful to have friends coming from distant quarters?" (You peng zi yuan fang lai, bu yi le hu, 有朋自远方来, 不亦乐乎) Compared with his article in The Chinese Repository, he applied a more modest and polite tone. We can see how he adjusted himself to achieve his religious mission and change the label of "barbarians" at that time. The Eastern Western Monthly Magazine is exactly a combination of Confucianism and Protestantism.

From other newspapers, it can also be seen how the meaning of $y i$ as barbarians was constructed. For example, on May 17, 1828, The Canton Register [24] published a Barbarians letter from an English Reader.
The reader said, "For as the pagan Greeks and Romans, excluding themselves, called the rest of the world barbarians, so the modern Christians of Europe call all the rest of the world 'uncivilized' which is equivalent, I fancy, to barbarian...I think it is very likely the Chinese mean by their native term something like... the ancient term barbarian." [25]. In the eyes of the British, barbarian means uncivilized. The equalization of $y i$ and barbarians meant that $y i$ was given the meaning of "uncivilized."

To sum up, the idea of the Celestial Empire in China and Gützlaff's experience had influenced his translation of the Chinese character $y i$ as barbarians.

\section{HOW THE HUA-YI DISTINCTION BECAME A DISTINCTION BETWEEN CHINESE AND FOREIGNERS}

Although Gützlaff understood $y i$ as barbarians, the word "barbarians" did not become a diplomatic issue until the end of the Second Opium War (1856-1860). Lin Zexu (1785-1850), the imperial commissioner of China, and his translator Shaow-Tih (Yuan Dehui, 袁德辉) did not use "barbarians" when communicating with other countries as representatives of the Chinese government but used "foreigners" to call foreigners. In July 1839, The Chinese Repository published an article called The First Document Which Ever Came from the Chinese in the English Language [26], written by Lin. The editor of The Chinese Repository said, "It is evidently the work of the commissioner's senior interpreter, who has for many years been in the employment of the government, at Peking. Its idioms are perfectly Chinese; and like all the documents in their own language, it is without punctuation." [27] In this document, Lin welcomed British businessmen to trade, but underlined that Britain could not sell opium to China, noting that "never will treat you, foreigners, by two manners of ways."

Also, in the letter that Lin wrote to the Queen Victoria of England, published in February 1840, Lin's translator did not use the word "barbarians," but "foreigners." However, he expressed deep dissatisfaction and anger at Britain's export of large quantities of opium to China. For example, he said,

"Every native of the Inner Land who sells opium, as also all who smoke it, are alike sentenced to death. Were we then to go back and take up the crimes of the foreigners, who, by selling it for many years have induced dreadful calamity and robbed us of enormous wealth, and punish them with equal severity, our laws could not but award to them absolute annihilation! But, considering that these said foreigners did yet repent of their crime, and with a sincere heart beg for mercy; that they took 20,283 chests of opium piled up in their storeships, and through Elliot, the superintendent of the trade of your said country, petitioned that they might be 
delivered up to us when the same were all utterly destroyed." [28]

The original text in Chinese was “若追究夷 (yi)人历 年贩卖之罪, 则其贻害深而算利重, 本为法所当诛 。惟念众夷 $(y i)$ 尚知悔罪乞诚, 将歪船鸦片二万二 百八十三箱, 由领事官义律, 禀请缴收, 全行毁化 。” Compared with the English version, yi was translated as foreigners by Shaow-Tih. He once worked as an interpreter for Lin to help with the anti-smoking campaign in 1839. Hunter recorded that, "An English translation of a communication addressed by His Excellency... to Her Majesty of Queen of England, on the subject of the opium trade, was brought to me at the Consoo House to be translated into Chinese, as a test of the proper reading of the original, which turned out to have been made by my old classmate Shaow-Tih." [29] It can be seen that Lin took a cautious attitude towards translation, and Shaow-Tih's translation of $y i$ as foreigners was approved by Lin Zexu.

But after two opium wars, $y i$ and barbarians seemed to be equivalent. After the First Opium War, Henry Pottinger (1789-1856), who signed the Treaty of Nanking (1842), clearly put forward, " $y i$ is not good, and I hope not to use it again." [30] The Second Opium War was caused by the desire of Britain and France to amend the treaty. They required more freedom and opportunities for trade, the presence of the Permanent Minister of Beijing to facilitate trade and negotiations, and more importantly, the realization of "equality" like between China and Britain. Britain believed that the exchange of ministers in respective capital was a general rule of exchanges between equal sovereign states. Otherwise, China would be contemptuous and arrogant. Therefore, the British negotiator James Bruce in the requirements of the covenant, put forward, "In accordance with the rule among Western states, the officials of one country can arbitrarily enter another." (Zhao tai xi zhu da bang xiang lai heng su jiao yi cheng gui, ge tu da li de yi ren yi jin yi $s h i$, 照泰西诸大邦向来恒素交谊成规, 各土大吏得以 任意进诣师) [31] Although at last ministers were allowed to live in Beijing, they had to bow down to the Chinese emperor. How could Britain and France accept it? So the Article III of Peace Treaty between the Queen of Great Britain and the Emperor of China (1858) was,

“His Majesty the Emperor of China hereby agrees that the ambassador, minister, or other diplomatic agents, ... may reside, with his family and establishment, permanently at the capital, or may visit it occasionally, at the option of the British Government. He shall not be called upon to perform any ceremony derogatory to him as representing the Sovereign of an independent nation on a footing of equality with that of China." [32]

The treaty addresses a number of political, cultural, and economic requirements, in which equality was emphasized. British demand for equality raised the issue of $y i$ to the table of negotiation. The Article LI of the treaty was "it is agreed, that henceforward the character

“I” 夷 ("barbarian") [33] shall not be applied to the Government or subjects of Her Britannic Majesty, in any Chinese official document issued by the Chinese authorities, either in the capital or in the provinces." [34] The article shows that hua-yi distinction has become a diplomatic issue between China and Britain, indicating that $y i$ was formally translated as barbarians and remained in history.

\section{CONCLUSION}

Our argument is that "barbarian" was invented. Different people changed the connotation of yi to suit their interests. It was first transformed by the Qing court from "barbarians" to those who following Confucianism to justify its rule, and it was translated as "foreigners" when Europeans came to China and retranslated as "barbarians" afterward. By situating these transformations in their contexts, our study explains some of the labels and misconceptions involved. On this basis, the shift in the meaning of $y i$ in other historical periods can be further explored. They will help us better understand how xenophobia and racism were and are constructed.

\section{REFERENCES}

[1] Henk Schulte Nordholt (2018). China and the Barbarians: Resisting the Western World Order. Leiden University Press. p.15.

[2] Liu He. (2000). The world beyond the light of European street lamps and revisiting the major new changes in Western scholarship. Dushu (05),66-74. doi: CNKI:SUN:DSZZ.0.2000-05-016.p.3.5-7.

[3] Liu He. (2000). The world beyond the light of European street lamps and revisiting the major new changes in Western scholarship. Dushu(05),66-74. doi: CNKI:SUN:DSZZ.0.2000-05-016.p.2.

[4] Wang Jiping. (1987). An evaluation of missionary cultural activities in China after the Opium War. Guangzhou yanjiu (05),59-61. doi: CNKI:SUN:KFSD.0.1987-05-017.p.1.

[5] Li Qianyu. (2013). A trial of the establishment of the foreign envoy system in China - and the decline of the hua-yi system of thought. Shehui kexue zhanxian (02),99-104. doi: CNKI:SUN:SHZX.0.2013-02018.p.1.

[6] Wang Kaixi. (2001). Reading history and talking about yi. Zhongguo dianji yu wenhua(02),21-25. doi: 10.16093/j.cnki.ccc.2001.02.006.p.2-3.

[7] Meng Hongli. (2018). From yi to guests: key points in the transformation of the discernment between yi- 
xia in the late Qing dynasty. Shehui kexue zhanxian (01),208-220. doi: CNKI:SUN:SHZX.0.2018-01020.p.2.p.3.

[8] Xiang Yuchen. (1996). The Changing Concepts of China and Yi and the Formation of the Closed-door Policy in the Qing dynasty. Sichuan shifan daxue xuebao (01), doi: CNKI:SUN:SCSF.0.1996-01019.p.2.

[9] Li kejian. (2018). A Study of the Multi-Ethnic "Oneness" of the Qing dynasty and its Policy Practices.Xinan minzu daxue xuebao (12),25-31. doi:CNKI:SUN:XNZS.0.2018-12-004.p.2.

[10] Meng qinbo, Liu caiyan.(2010). The Chinese Rites Controversy between Christianity and China. Hebei ligong daxue xuebao (06),96-99. doi: CNKI:SUN:HLXB.0.2010-06-029.p.3.

[11] Chen Caijun. (2008). An analysis of Morrison and early Sino-British diplomatic relations.Guangdong shehui kexue (05),111-117. doi: CNKI:SUN:GDSK.0.2008-05-021.p.1.p.3.p.6-7.

[12] Zhang Yongguang. (2020). An exploration of the physical presence and spatial construction of Christian missionaries to China in the late Qing dynasty. Shijie zongjiao yanjiu (03),144-153. doi: CNKI:SUN:WORL.0.2020-03-016.p.4.

[13] Liu, L. H. (2004). The clash of empires. Harvard University Press.p.41-42.

[14] Wang Hongzhi. (2013). Morrison and the "barbarian's eye" .Dongfang Fanyi (02),28-35. doi: p.6-7.

[15] “外夷” means Yi in foreign countries

[16] Wiley Alexander (1867). Memorials of Protestant Missionaries to the Chinese: Giving a List of Their Publications, and Obituary Notices of the Deceased. Shanghae: American Presbyterian mission press. p.55.

[17] Gützlaff, K., \& Ellis, W. (2015). Brief Notice of China and Siam, and the Labours of Protestant Missionaries in these and the adjacent Countries. In Journal of Three Voyages along the Coast of China, in 1831, 1832 and 1833: With Notices of Siam, Corea, and the Loo-Choo Islands (Cambridge Library Collection - East and South-East Asian History, pp. Xv-Cviii). Cambridge: Cambridge University Press. p. lxxvi. doi:10.1017/CBO9781316018255.003

[18] Gützlaff, p.lxxv.

[19] Gützlaff, K., \& Ellis, W. (2015). Brief Notice of China and Siam, and the Labours of Protestant Missionaries in these and the adjacent Countries. In
Journal of Three Voyages along the Coast of China, in 1831, 1832 and 1833: With Notices of Siam, Corea, and the Loo-Choo Islands (Cambridge Library Collection - East and South-East Asian History, pp. Xv-Cviii). Cambridge: Cambridge University Press. $\quad$ p. 28. doi:10.1017/CBO9781316018255.003

[20] Lydia H. Liu (2004). The Clash of Empires: The Invention of China in Modern World Making. Cambridge, MA: Harvard University Press. p.54.

[21] Elijah Coleman Bridgman, S. W. Williams (1834). The Chinese Repository VOL. II (from May, 1833 to April, 1834). Canton: Printed for the proprietors. p.186.

[22] Karl Friedrich August Gützlaff (1833). Eastern Western Monthly Magazine. (from Aihanzhe, etc. editor, Huang Shixuan finishing (1997). Eastern Western Monthly Magazine. Beijing: Zhonghua Shuju. p.23.)

[23] Which is “远客 (Yuanke)” in Chinese

[24] The Canton Register, an English-language newspaper founded by Westerners in China in the early 19th century. The paper was founded by James Matheson, a British businessman and was published in Guangzhou on 8th November, 1827.

[25] “Barbarians,” The Canton Register, 17 May 1828.

[26] Elijah Coleman Bridgman, S. W. Williams (1840). The Chinese Repository VOL. VIII (from May, 1839 to April, 1840). Canton: Printed for the proprietors. p. 186 .

[27] Elijah Coleman Bridgman, S. W. Williams (1840). The Chinese Repository VOL. VIII (from May, 1839 to April, 1840). Canton: Printed for the proprietors. p.186.

[28] The Chinese Repository, Vol. 8 (February 1840), pp. 497-503; reprinted in William H. McNeil and Mitsuko Iriye, eds., Modern Asia and Africa, Readings in World History Vol. 9, (New York: Oxford University Press, 1971), pp. 111-112.

[29] William C. Hunter (1885). Bits of Old China. London: K. Paul, Trench, \& co. p.262-263. [29] C. Baier, J-P. Katoen, Principles of Model Checking, MIT Press, 2008.

[30] Association of Chinese Historians (1978). China Modern History Materials Series, The Opium Wars. Shanghai shu dian chu ban she. p.389

[31] Preparation of the Beginning and End of the yi Affairs (Xianfeng dynasty) (Volume II), edition of the Chinese Book Bureau, p. 654. 
[32] Treaty of Tien-Tsin between the Queen of Great Britain and the Emperor of China (1858). The article in Chinese is “大英钦差各等大员及各眷属可在 京师, 或长行居住, 或能随时往来, 总候奉本 国诣旨遵行; 英国自主之邦与中国平等, 大英 钦差大臣作为代国秉权大员，觐大清皇上时， 遇有碍于国体之礼, 是不可行。惟大英君主每 有派员前往泰西各与国拜国主之礼, 亦拜大清 皇上, 以昭划一肃敬.”

[33] “夷” is called Yi in Chinese Pinyin, and in order not to be confused with the English subject I, yi is used to refer to '夷' .

[34] Treaty of Tien-Tsin between the Queen of Great Britain and the Emperor of China (1858). The article in Chinese is “第五十一款 嗣後各式公文, 無 論京外, 內敘大英國官民, 自不得提書夷字.” 